\title{
Author Correction: Tidal wetland resilience to sea level rise increases their carbon sequestration capacity in United States
}

\author{
Faming Wang (D), Xiaoliang Lu, Christian J. Sanders \& Jianwu Tang (1)
}

Correction to: Nature Communications https://doi.org/10.1038/s41467-019-13294-z, published online 28 November 2019.

The original version of this Article contained an error in the spelling of the author Faming Wang, which was incorrectly given as Farming Wang. This has now been corrected in both the PDF and HTML versions of the Article.

Published online: 11 December 2019

\begin{abstract}
(c) Open Access This article is licensed under a Creative Commons Attribution 4.0 International License, which permits use, sharing, adaptation, distribution and Ceproduction in any medium or format, as long as you give appropriate credit to the original author(s) and the source, provide a link to the Creative Commons license,

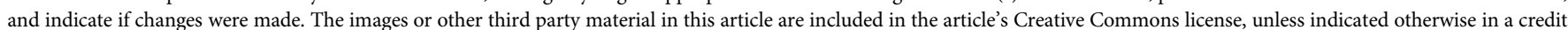
line to the material. If material is not included in the article's Creative Commons license and your intended use is not permitted by statutory regulation or exceeds the permitted use, you will need to obtain permission directly from the copyright holder. To view a copy of this license, visit http://creativecommons.org/licenses/by/4.0/.
\end{abstract}

(C) The Author(s) 2019 